\title{
Peran Notaris Dalam Penentuan Pembubuhan Sidik Jari Penghadap Dalam Minuta Akta
}

\author{
Tania Novelin¹, I Made Sarjana²
}

${ }^{1}$ Fakultas Hukum Universitas Udayana, E-mail: tanianovelin97@gmail.com 2Fakultas Hukum Universitas Udayana, E-mail: made_sarjana@unud.ac.id

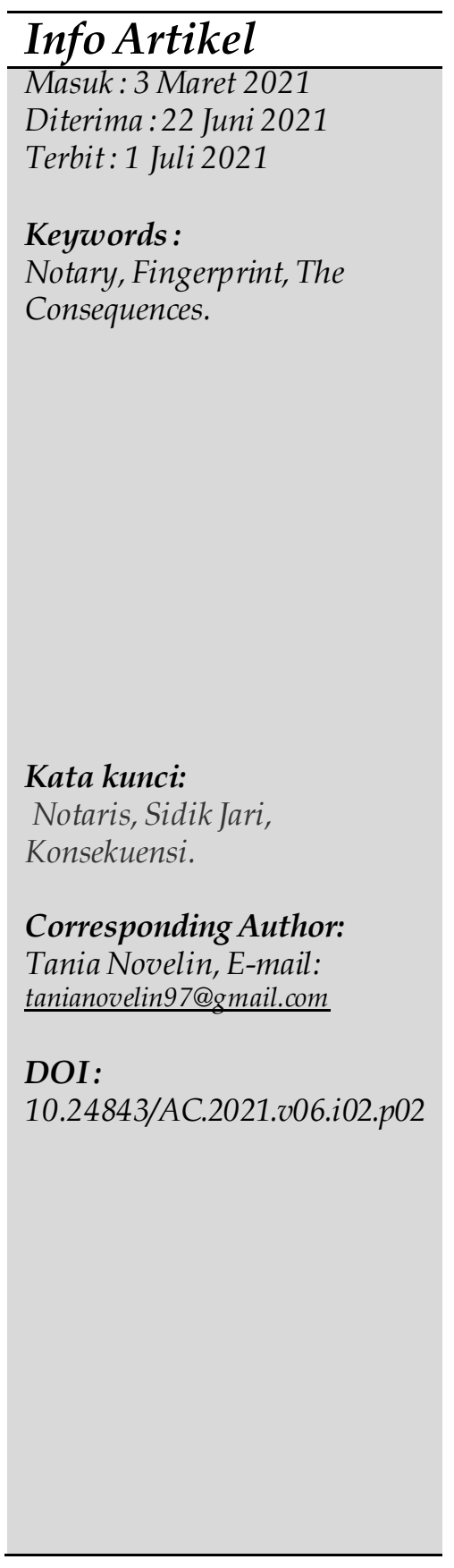

\begin{abstract}
This paper's purpose is to find out and examine the Notary's role in responding provisions of the Fingerprints of the Facilitators in the deeds of deeds and also to know and examine the consequences for Notaries for the Minutes of deeds with differentfingerprints affixed to the Facilitators. The method of legal research in this journal applies normative legal research, with an approach to law and analysis of legal concepts. The results showed that Notaries were free to use any interpretation regarding which fingerprints to be used and were free to determine which fingerprints were affixed to those who were able to sign or only parties who were unable to sign. In this case, the notary must consistently do it during his/her duties. Regarding the consequences for the Notary for the minimum number of deeds with different fingerprints on the faces, it is not further regulated in the statutory regulations so that the Notary cannot be sanctioned due to the inconsistency.
\end{abstract}

\section{Pendahuluan}

\begin{abstract}
Abstrak
Tujuan dari tulisan ini yakni untuk mengetahui dan mengkaji tentang peran Notaris dalam menyikapi ketentuan pembubuhan sidik jari Para Penghadap dalam minuta akta dan juga mengetahui dan mengkaji konsekuensi bagi Notaris terhadap minuta akta yang pembubuhan sidik jari Penghadapnya berbedabeda. Metode penelitian hukum dalam jurnal ini mengaplikasikan penelitian hukum normatif, dengan pendekatan UU dan analisis konsep hukum. Hasil penelitian menunjukkan Notaris bebas untuk menggunakan penafsiran manapun mengenai sidik jari mana yang akan dipakai dan bebas menentukan pembubuhan sidik jari dilakukan juga bagi Para Penghadap yang mampu untuk tanda tangan ataukah hanya penghadap/para pihak yang tidak mampu untuk tanda tangan. Dalam hal ini, Notaris harus konsisten melakukannya selama menjalankan tugas jabatannya. Mengenai konsekuensi bagi Notaris terhadap minuta akta yang pembubuhan sidik jari penghadapnya berbeda-beda tidak diatur lebih lanjut pada peraturan perundang-undangan sehingga Notaris tidak dapat dijatuhi sanksi akibat dari inkonsistensinya.
\end{abstract}

Notaris memiliki peran yang sangat besar di masyarakat karena Notaris mengimplementasikan wewenang Negara di bidang hukum perdata yakni hukum 
pembuktian melalui produknya berupa akta otentik. Keberadaan profesi Notaris untuk melayani masyarakat dan agar terciptanya kepastian hukum ${ }^{1}$. Oleh karena itu Notaris berkewajiban untuk mengkonstatir keterangan yang diungkap oleh Penghadap. Notaris juga wajib melakukan penyuluhan hukum kepada Para Penghadap terkait akta Notaris ${ }^{2}$. Selain itu juga Notaris sebagai penasehat hukum sesuai permasalahan yang dihadapi penghadap terkait akta Notaris ${ }^{3}$. Notaris berpedoman pada Undang-Undang Nomor 30 Tahun 2004 tentang Jabatan Notaris (selanjutnya disebut UU No. 30/2004), Kode Etik Notaris, dan peraturan perundang-undangan terkait saat menjalankan tugas jabatannya. UU No. 30/2004 yang diubah dengan Undang-Undang Nomor 2 Tahun 2014 (selanjutnya disebut UU No. 2/2014) mengatur mengenai Jabatan Notaris. UU No. 30/2004 lahir menggantikan "Reglement op Het Notaris Ambt in Indonesia (staatsblad 11 Januari 1860 No.3)" yang dianggap tak serupa lagi dengan hukum dan masyarakat yang berkembang. Pasal 1 angka (1) UU 2/2014 mengatur "Notaris adalah pejabat umum yang berwenang untuk membuat akta otentik dan memiliki kewenangan lainnya sebagaimana dimaksud dalam Undang-Undang ini atau berdasarkan undang-undang lainnya". Atas pengertian tersebut, berarti bahwa Notaris berwenangan merealisasikan akta otentik apabila kewenangan itu tidak diberikan kepada pejabat lain. ${ }^{4}$

Kata 'akta' berasal dari bahasa Belanda "acta", dalam bahasa Prancis "acte", dan "deed" dalam bahasa inggris. Akta diartikan sebagai tulisan atau surat ${ }^{5}$. Pada lazimnya, akta digolongkan atas akta otentik dan dibawah tangan. Mengenai arti akta otentik tercantum di Pasal 1868 KUHPerdata yang mengatur "akta otentik merupakan akta yang didalam bentuk yang ditentukan oleh undang-undang, dibuat oleh atau dihadapan pegawai-pegawai umum yang berkuasa untuk itu di tempat di mana akta dibuatnya". Akta itu harus ditandatangani agar bias digolongkan sebagai sebuah akta. Keharusan tersebut tercantum dalam Pasal 1869 KUHPerdata. Keharusan penandatanganan bertujuan agar dapat dibedakan antara akta yang satu dari akta yang lainnya. Penandatanganan merupakan pembubuhan nama dari si Penghadap di mana nama tersebut ditulis oleh Penghadap atas kehendaknya sendiri ${ }^{6}$. Pasal 16 (1) c UU No. 2/2014 mengatur "Notaris wajib melekatkan surat dan dokumen serta sidik jari penghadap pada minuta akta". Padahal, sebelumnya ketentuan mengenai kewajiban tersebut tidak diatur secara tegas dalam UU No. 30/2004. Pasal 1 angka 8 UU No. 2/2014 mengatur "Minuta Akta adalah asli Akta yang mencantumkan tanda tangan Para Penghadap, saksi, dan Notaris, yang disimpan sebagai bagian dari protokol Notaris". Pengertian tersebut mengandung kehendak UU No. 30/2004 yang mengharuskan para

1 Maharani, I. G. A. A. D. Kewenangan Notaris dalam Transaksi Jual Beli Tanah dan Bangunan: Studi Kasus Penahanan Sertipikat Hak Guna Bangunan. Kertha Patrika, 40(2), 112-121, h. 113., doi https:// doi.org/10.24843/KP.2018.v40.i02.p05

2 Dewi, W. W., \& Ibrahim, R. Kekuatan Hukum PelekatanSidik Jari Penghadap Oleh Notaris Pada Minuta Akta. Acta Comitas: Jurnal Hukum Kenotariatan, 5(3), 436-445, h. 437. doi https:/ / doi.org/10.24843/ AC.2020.v05.i03.p01

3 Anand, G. (2017). Keabsahan Akta Notaris Kaitannya dengan Kewajiban Pembubuhan Sidak Jari Penghadap. Lambung Mangkurat Law Journal,2(1), 144856, h. 32., e-ISSN: 2502-3128, http://lamlaj.ulm.ac.id/web/

4 Ratnawati, A. (2015). Peranan Notaris Untuk Pembuatan Akta Pendirian (CV) dalam Merujudkan Kepastian Hukum (Doctoral dissertation, Sebelas Maret University).

5 H.Salim, et.al. (2014). Perancangan KontrakEMemorandum of Understanding (MoU). Jakarta: Sinar Grafika. h.29

6 Ibid, h.152. 
penghadap untuk menandatangani akta, bukan membubuhkan sidik jari. ${ }^{7}$ Dalam UU No. 2/2014 telah terjadi pergeseran perihal kewajiban dibubuhinya sidik jari penghadap pada minuta akta. Di UU No. 30/2004, bukanlah suatu kewajiban untuk dibubuhinya sidik jari penghadap, sedangkan dalam UU No. 2/2014, pelekatan sidik jari penghadap menjadi suatu kewajiban oleh Notaris 8 . Tanda tangan dan sidik jari penghadap menurut Notaris berfungsi sebagai tanda diri yang bersangkutan, sebagai bukti Penghadap telah menghadap Notaris, dan sebagai persetujuan Penghadap tentang yang tertuang dalam akta9 . Mengenai hal tersebut, dalam Pasal 16 ayat 1 (c) UU No. 2/2014 tidak dijelaskan secara tegas mengenai cara membubuhkan sidik jari tersebut. Dalam penjelasannya hanya disebutkan bahwa pasal tersebut "Cukup Jelas". Selain itu juga terdapat ketidaksinkronan Pasal 16 (1) c dengan Pasal 1 (8) UU No. 2/2014 karena dalam Pasal 1(8) UU No. 2/2014 tidak mengatur kewajiban Notaris seperti Pasal 16 ayat 1 (c) UU No. 2/201410. Berdasarkan uraian latar belakang tersebut, adapun permasalahan yang dipaparkan yaitu bagaimana peran Notaris dalam menyikapi ketentuan membubuhi sidik jari Para Penghadap dalam minuta akta dan bagaimanakah konsekuensi untuk Notaris terhadap minuta akta yang pembubuhan sidik jari Penghadapnya berbeda-beda.

Tujuan dalam penulisan ini yakni mengetahui dan mengkaji tentang peran Notaris dalam menyikapi ketentuan pembubuhan sidik jari Para Penghadap dalam minuta akta dan juga mengetahui dan mengkaji konsekuensi bagi Notaris terhadap minuta akta yang pembubuhan sidik jari Penghadapnya berbeda-beda. Penelitian terdahulu dilakukan oleh Arief Rahman Mahmoud pada tahun 2014 yang berjudul "Implikasi Hukum Bagi Notaris Yang Tidak Melekatkan Sidik Penghadap Pada Minuta Akta"11. Penelitian tersebut berfokus pada "implikasi hukum bagi Notaris yang tidak melekatkan sidik jari penghadap pada minuta akta", yakni dikenakan sanksi sebagaimana Pasal 16 ayat (11) UU No. 2/2014 (11) mengatur "Notaris yang melanggar ketentuan sebagaimana dimaksud pada ayat (1) huruf a sampai dengan huruf 1 dapat dikenai sanksi berupa:

a. peringatan tertulis;

b. pemberhentian sementara;

c. pemberhentian dengan hormat; atau

d. pemberhentian dengan tidak hormat".

Sedangkan penelitian yang dilakukan penulis berfokus pada konsekuensi bagi Notaris terhadap minuta akta yang pembubuhan sidik jari Penghadapnya berbeda-beda. Penelitian selanjutnya dilakukan oleh Rizka Rahmawati pada tahun 2019 berjudul "Implementasi Kewajiban Notaris untuk Melekatkan Sidik Jari Para Penghadap pada Minuta Akta"12.

7 Mahmoud, A. R. (2014). Implikasi Hukum Bagi Notaris Yang Tidak Melekatkan Sidik Jari Penghadap Pada Minuta Akta. Kumpulan Jurnal Mahasiswa Fakultas Hukum, 1(1), E-ISSN 2723-3766, h.63., https:/ / e-iournal.fh.unmul.ac.id/index.php/risalah/article/view/101

8 NIGITA, V. (2017). URGENSI DAN IMPLIKASI HUKUM PENERAPAN SIDIK JARI PENGHADAP/PARA PENGHADAP/PARA PIHAK PADA MINUTA AKTA NOTARIS (STUDI TERHADAP PASAL 16 AYAT (1) HURUF C UNDANG-UNDANG NOMOR 2 TAHUN 2014 TENTANG JABATAN NOTARIS) (Doctoral dissertation, Universitas Islam Indonesia).

9 Habib Adjie. (2017). Penafsiran Tematik Hukum Notaris Indonesia Berdasarkan Undang-Undang Nomor 2 Tahun 2014 tentang Perubahan Atas Undang-Undang Nomor 30 Tahun 2004 tentang Jabatan Notaris. Bandung : Refika Aditama. h.21.

10 Dewi, A. S. K. (2016). Penyelenggaraan RUPS MelaluiMedia Elektronik Terkait Kewajiban Notaris Melekatkan Sidik Jari Penghadap. Arena Hukum, 8(1), 108-126, h. 110, doi https:/ / doi.org/10.21776/ub.arenahukum.2015.00801.7

11 Mahmoud, A. R., Loc.Cit.

12 Rahmawati, R. (2019). Implementasi Kewajiban Notaris untuk Melekatkan Sidik Jari Para Penghadap pada Minuta Akta. Sasi, 25(1),1-12, h. 2, doi https://doi.org/10.47268/sasi.v25i1.138 
Penelitian tersebut berfokus pada "kewajiban Notaris dalam melekatkan lembaran berisi sidik jari penghadap pada minuta akta berdasarkan UU No. 2/2014 dan kedudukan akta notaris yang tidak melekatkan sidik jari penghadap serta sanksi bagi Notaris yang tidak dibubuhi sidik jari penghadap dalam minuta akta". Sedangkan penelitian yang diteliti oleh Penulis berfokus perihal konsekuensi bagi Notaris terhadap minuta akta yang pembubuhan sidik jari Penghadapnya berbeda-beda. Berdasarkan pendahuluan ini, maka Penulis tertarik mengangkat judul "Peran Notaris Dalam Penentuan Pembubuhan Sidik Jari Penghadap Dalam Minuta Akta".

\section{Metode Penelitian}

Penelitian hukum normatif dalam jurnal ini dilakukan dengan mengacu pada peraturan tertulis atau bahan hukum ${ }^{13}$. Pendekatan UU dan analisis konsep hukum merupakan pendekatan yang diaplikasikan dalam jurnal ini. Sumber penelitian yang digunakan yakni berasal dari bahan hukum primer yang terdiri atas peraturan perundang-undangan, dan bahan hukum sekunder yang terdiri atas buku dan hasil-hasil penelitian seperti jurnaljurnal. Pengumpulan bahan hukum di jurnal ini menggunakan teknik studi kepustakaan. Penelitian jurnal ini menggunakan sistem kartu (card system) yaitu dengan mencari bahanbahan dalam literatur, peraturan perundang-undangan, artikel ilmiah, dan pendapat para sarjana yang terkait dengan permasalahan. Setelah itu dicatat dalam satu kartu agar mudah untuk melakukan analisis. Teknik deskripsi merupakan metode analisis bahan hukum yang digunakan dalam jurnal ini merujuk pada peraturan UU terkait, literatur-literatur yang dikumpulkan terkait permasalahan jurnal ini.

\section{Hasil Dan Pembahasan}

\subsection{Peran Notaris Dalam Menyikapi Berbagai Penafsiran Mengenai Ketentuan Pembubuhan Sidik Jari Para Penghadap Dalam Minuta Akta}

Pasal 1(8) UU No. 30/2004 mengatur "Minuta akta adalah asli akta Notaris" sebagaimana dalam UU No. 2/2014 diubah menjadi "Minuta Akta adalah asli Akta yang mencantumkan tanda tangan Para Penghadap, saksi, dan Notaris, yang disimpan sebagai bagian dari protokol Notaris". Berdasarkan pengertian tersebut berarti tanda tangan ketiga unsur/pihak tersebut harus ada dalam minuta akta. Substansi Pasal 1 (8) dalam UU No. 30/2004 dan UU No. 2/2014 berbeda. Dalam UU No. 30/2004, Pasal 1 angka 8 tersebut tidak menegaskan bahwa Minuta Akta harus mencantumkan tanda tangan Penghadap, yang berarti bahwa Penghadap boleh membubuhkan sidik jari baik yang mampu tanda tangan maupun yang tidak mampu untuk tanda tangan, ataupun Penghadap boleh mencantumkan kedua-duanya sebagai kehati-hatian Notaris. Namun, Pasal 1 angka (8) UU No. 2/2014 menegaskan keharusan mencantumkan tanda tangan sebagaimana tersebut diatas. Pasal 1 angka (8) UU No. 2/2014 tidak menegaskan mengenai Penghadap yang tidak mampu untuk tanda tangan. Namun, Pasal tersebut harus dihubungkan dengan Pasal 16 (1) c UU No. 2/2014. Pasal 16 (1) c UU No. 2/2014 mengatur "Dalam menjalankan jabatannya, Notaris wajib melekatkan surat dan dokumen serta sidik jari penghadap pada Minuta Akta".

Pasal itu tidak tegas mengatur mengenai prosedur pembubuhan sidik jari apakah menggunakan minuta akta yang dilekatkan lembaran kertas tersendiri, selain itu juga tidak

${ }^{13}$ Suratman dan H.Philips Dillah. (2015). Metode Penelitian Hukum. Bandung: Alfabeta. h. 51 
dijelaskan mengenai siapa yang wajib membubuhkan sidik jari tersebut, apakah seluruh penghadap walaupun telah menandatangani minuta akta ataukah yang tidak mampu tanda tangan saja. Mengenai seluruh sidikjari tangan atau sidik jari tertentu saja yang digunakan juga tidak diatur dalam Pasal tersebut. Mengenai hal tersebut, terdapat beberapa pendapat atau penafsiran mengenai Pasal 16 ayat 1 (c), yaitu:

1. "Penghadap yang bisa tanda tangan tetap membubuhkan tanda tangannya pada lembar kertas/lembaran Minuta Akta, juga untuk membubuhkan sidik jarinya dengan penghadap yang tidak bisa membubuhkan tanda tangannya pada kertas/lembaran tersendiri (lembaran kertas yang sama atau dibuat untuk tiap penghadap) yang akan dilekatkan pada Minuta Akta yang bersangkutan. Dengan kata lain, untuk penghadap yang bisa tanda tangan, tetap membubuhkan tanda tangan dan sidik jarinya.

2. Penghadap yang bisa tanda tangan wajib membubuhkan tanda tangannya pada kertas/lembaran minuta, sedangkan yang tidak bisa tanda tangan harus membubuhkan sidik jarinya pada kertas/lembaran tersendiri yang akan dilekatkan pada Minuta Akta bersangkutan"14.

Berkaitan dengan penandatanganan tersebut, Pasal 44 UU No. 2/2014 juga mengatur :

(1) "Segera setelah Akta dibacakan, Akta tersebut ditandatangani oleh setiap penghadap, saksi, dan Notaris, kecuali apabila ada penghadap yang tidak dapat membubuhkan tanda tangan dengan menyebutkan alasannya.

(2) Alasan sebagaimana dimaksud pada ayat (1) dinyatakan secara tegas pada akhir Akta.

(3) Akta sebagaimana dimaksud dalam Pasal 43 ayat (3) ditandatangani oleh penghadap, Notaris, saksi, dan penerjemah resmi.

(4) Pembacaan, penerjemahan atau penjelasan, dan penandatanganan sebagaimana dimaksud pada ayat (1) dan ayat (3) serta dalam Pasal 43 ayat (3) dinyatakan secara tegas pada akhir Akta.

(5) Pelanggaran terhadap ketentuan sebagaimana dimaksud pada ayat (1), ayat (2), ayat (3), dan ayat (4) mengakibatkan suatu Akta hanya mempunyai kekuatan pembuktian sebagai akta di bawah tangan dan dapat menjadi alasan bagi pihak yang menderita kerugian untuk menuntut penggantian biaya, ganti rugi, dan bunga kepada Notaris".

Pasal 44 (1) dan (2) UU No. 2/2014 berlaku bagi Penghadap yang tidak mampu tanda tangan pada lembaran/kertas Minuta dengan alasan tertentu. Ada 2 (dua) kemungkinan alasan Penghadap tidak bisa tanda tangan, yakni ${ }^{15}$ :

1. "Penghadap mampu baca tulis tetapi tidak mampu menandatangan karena secara fisik sakit keras di tangan atau tidak mempunyai jari tangan. Perihal itu, maka yang dipakai adalah 'surrogate'. 'Surrogate' merupakan pengganti tanda tangan apabila Penghadap tidak mampu tanda tangan dan keterangan dari Penghadap bahwa ia tidak dapat membubuhkan tanda tangannya, dan hal tersebut dituliskan oleh Notaris dan dinyatakan dengan tegas dalam akta. Hal tersebut disebut "keterangan terhalang untuk menulis".

\footnotetext{
${ }^{14}$ Habib Adjie, Op.Cit, h. 29.

${ }^{15}$ Ibid.
} 
2. Secara fisik penghadap sehat, tetapi tidak mampu baca tulis. Dalam keadaan ini, Penghadap harus membubuhkan sidik jarinya. Hal ini disebut "keterangan tidak dapat menulis".

Notaris dalam hal ini berperan sebagai "decision maker" yang artinya mengambil keputusan dalam menyikapi hal-hal terkait tugas jabatannya. Dalam hal ini, Notaris bebas untuk menerapkan pendapat/penafsiran yang mana saja. Hal yang esensial adalah Penghadap mau melakukannya didasarkan permintaan Notaris. Notaris juga harus konsisten untuk melakukannya selama melakukan tugas jabatannya, misalnya: Notaris berpendapat bahwa penghadap harus menandatangani dan membubuhi sidik jari pada lembaran tersendiri, maka Notaris harus konsisten untuk menerapkan hal tersebut selama menjalankan tugas jabatannya apakah menerapkan sidik jari tangan kiri atau kanan, menggunakan keseluruhan jari atau beberapa saja. Dalam kaitannya dengan hal tersebut, terdapat beberapa ketentuan mengenai penggunaan sidik jari tersebut untuk akta dibawah tangan, yakni Pasal 1874 KUHPerdata mengatur "Dengan penandatanganan sepucuk surat di bawah tangan dipersamakan suatu cap jempol, dibubuhi dengan suatu pernyataan yang bertanggal dari seorang notaris atau seorang pegawai lain yang ditunjuk oleh undangundang dari mana ternyata bahwa ia mengenal si pembubuh cap jempol, atau bahwa orang ini telah diperkenalkan kepadanya, bahwa isinya akta telah dijelaskan kepada orang itu, dan bahwa setelah itu cap jempol tersebut dibubuhkan di hadapan pegawai tadi. Pegawai ini harus membukukan tulisan tersebut. Dengan undang-undang diadakan aturan-aturan lebih lanjut tentang pernyataan dan pembukuan termaksud". Dikarenakan Pasal 16 ayat 1 (c) UU NO. 2/2014 tidak memberikan penjelasan mengenai sidik jari mana yang dilekatkan, maka dapat dinterpretasi sidik jari manapun dapat dibubuhi asalkan Notaris konsisten ${ }^{16}$. Seperti contoh: jika ingin menerapkan sidik ibu jari kanan, maka seterusnya menggunakan sidik ibu jari kanan selama menjalankan tugas jabatannya. Jika ingin menerapkan 10 (sepuluh) jari tangan, maka terus menggunakannya selama menjalankan tugas jabatan ${ }^{17}$. Oleh sebab itu, maka akan ada keragaman pembubuhan sidik jari penghadap yang dilakukan oleh Notaris di Indonesia. Ada Notaris yang menentukan penghadap untuk membubuhkan tanda tangan dan juga sidik jari pada lembaran terpisah yang telah disiapkan Notaris, dan juga ada Notaris yang menentukan penghadap untuk tanda tangan saja jika penghadap mampu. Dan bagi penghadap yang tak mampu tanda tangan dikarenakan suatu hal, melekatkan sidik jarinya. Selain itu juga ada keragaman dalam dalam hal pelekatan sidik jari tersebut. Ada Notaris yang menentukan sidik ibu jari kanan atau kiri, dan ada juga yang menerapkan 10 (sepuluh) jari tangan. Mengenai hal tersebut, di bidang hukum perdata biasanya diambil sidik jempol yang sewaktu-waktu dari jempol kanan atau jempol kiri. Oleh Karena itu, maka perlu diatur secara tegas mengenai sidik jari ini misalnya diatur secara tegas bahwa yang digunakan adalah sidik jempol kanan atau sidik jempol kiri agar adanya keseragaman karena Notaris akan selalu dihadapi oleh persoalan mengenai sidik jari.

\subsection{Konsekuensi Bagi Notaris Terhadap Minuta Akta Yang Pembubuhan Sidik Jari Penghadapnya Berbeda-Beda}

${ }^{16}$ Habib Adjie, Op.Cit, h.22-23.

17 Ibid. 
Konsekuensi merupakan hasil akhir atau dampak dari dilakukannya suatu perbuatan. Salah satu contoh dari konsekuensi adalah adanya sanksi. Dalam UU No. 30/2004, sanksi bagi Notaris dan akta Notaris tertuang dalam Pasal 84 dan Pasal 85, dan dalam UU No. 2/2014, pada Pasal terkait langsung diatur mengenai sanksi. Tujuan dari adanya sanksi yakni agar Notaris bertindak sesuai dengan aturan sehingga dapat menghasilkan output berbentuk akta otentik yang perlindungan dan kepastian hukum bagi masyarakatnya terjamin. Sanksi terhadap akta Notaris yakni akta itu menjadi dibawah tangan. Hal tersebut dapat dijadikan alasan pengahadap untuk menuntut ganti rugi kepada Notaris. Sanksi tersebut disebut dengan sanksi perdata. Dalam UU No. 2/2014, sanksi ditujukan kepada:

1. "Akta Notaris terdegradasi menjadi akta dibawah tangan.

2. Terhadap Notarisnya (jabatannya) dapat dikenakan sanksi administratif.

3. Terhadap Notarisnya dapat dituntut ganti rugi dikarenakan akta terdegradasi sebagai akta dibawah tangan".

Adapun sanksi yang diatur dalam beberapa Pasal UU No. 2/2014, yakni:

1. Pasal 16 (9) mengatur "Jika salah satu syarat sebagaimana dimaksud pada ayat (1) huruf $\mathrm{m}$ dan ayat (7) tidak dipenuhi, Akta yang bersangkutan hanya mempunyai kekuatan pembuktian sebagai akta di bawah tangan", Pasal 41 mengatur "Pelanggaran terhadap ketentuan sebagaimana dimaksud dalam Pasal 38, Pasal 39, dan Pasal 40 mengakibatkan Akta hanya mempunyai kekuatan pembuktian sebagai akta di bawah tangan".

2. "Sanksi administratif saja" sebagaimana Pasal 7 (2) mengatur "Notaris yang melanggar ketentuan sebagaimana dimaksud pada ayat (1) dapat dikenai sanksi berupa:
a. peringatan tertulis;
b. pemberhentian sementara;
c. pemberhentian dengan hormat; atau
d. pemberhentian dengan tidak hormat"

Begitu juga dalam Pasal 17, 19, 32, 54, dan 65A. Pasal 37 mengatur "Notaris yang melanggar ketentuan sebagaimana dimaksud pada ayat (1) dapat dikenai sanksi berupa:
a. peringatan lisan;
b. peringatan tertulis;
c. pemberhentian sementara;
d. pemberhentian dengan hormat; atau
e. pemberhentian dengan tidak hormat".

Pasal 16 angka (13) UU No. 2/2014 mengatur "Notaris yang melanggar ketentuan sebagaimana dimaksud pada ayat (1) huruf n dapat dikenai sanksi berupa peringatan tertulis".

3. "Akta Notaris terdegradasi menjadi akta dibawah tangan disertai sanksi" sebagaimana diatur dalam Pasal 44 ayat (4) mengatur "Pelanggaran terhadap ketentuan sebagaimana dimaksud pada ayat (1), ayat (2), ayat (3), dan ayat (4) mengakibatkan suatu Akta hanya mempunyai kekuatan pembuktian sebagai akta di bawah tangan dan dapat menjadi alasan bagi pihak yang menderita kerugian untuk menuntut penggantian biaya, ganti rugi, dan bunga kepada Notaris". Sanksi ini juga 
diatur dalam Pasal 48 ayat (3), Pasal 49 ayat (4), dan Pasal 50 ayat (5), dan Pasal 51 ayat (4).

4. "Sanksi administratif yang dapat dijatuhi sanksi perdata" sebagaimana dalam Pasal 16 angka (11) mengatur "Notaris yang melanggar ketentuan sebagaimana dimaksud pada ayat (1) huruf a sampai dengan huruf 1 dapat dikenai sanksi berupa:
a. peringatan tertulis;
b. pemberhentian sementara;
c. pemberhentian dengan hormat; atau
d. pemberhentian dengan tidak hormat".

Pasal 16 angka (12) mengatur "Selain dikenai sanksi sebagaimana dimaksud pada ayat (11), pelanggaran terhadap ketentuan Pasal 16 ayat (1) huruf $\mathrm{j}$ dapat menjadi alasan bagi pihak yang menderita kerugian untuk menuntut penggantian biaya, ganti rugi, dan bunga kepada Notaris".

Pasal 73 (1) huruf e mengatur "Majelis Pengawas Wilayah berwenang memberikan sanksi baik peringatan lisan maupun peringatan tertulis". Dan ayat 3 nya mengatur "Terhadap setiap keputusan penjatuhan sanksi sebagaimana dimaksud pada ayat (1) huruf e dan huruf $f$ dibuatkan berita acara".

Pasal 16 (1) c UU No. 2/2014 tersebut termasuk kewajiban hukum dari Notaris. Sebagaimana pada dasarnya, teori kewajiban hukum menurut Hans Kelsen terkait dengan konsep sanksi. Yang diwajibkan secara hukum sebagai berikut 18 :

1. individu yang perilakunya dapat berakibat terhadap suatu pelanggaran yang menimbulkan sanksi.

2. Individu yang perilakunya dapat menghindari sanksi dengan berperilaku sebaliknya

Berdasarkan hal tersebut, dapat diketahui bahwa dalam UU No. 2/2014 tidak mengatur secara tegas mengenai konsekuensi bagi Notaris apabila Notaris tersebut inkonsisten dalam membubuhi sidik jari Penghadap. UU No. 2/2014 hanya mengatur mengenai apabila Notaris tidak melakukan kewajibannya itu, Notaris terkena sanksi administrasi pada Pasal 16 ayat (11) UU No. 2/2014 mengatur "Notaris yang melanggar ketentuan sebagaimana dimaksud pada ayat (1) huruf a sampai dengan huruf 1 dapat dikenakan sanksi berupa:

a. Peringatan tertulis;

b. Pemberhentian sementara;

c. Pemberhentian dengan hormat; atau

d. Pemberhentian dengan tidak hormat".

Secara normatif hal tersebut tidak berpengaruh terhadap Notaris maupun kedudukan hukum akta Notaris dikarenakan belum ada aturan mengenai sanksi apabila Notaris inkonsisten membubuhi sidik jari Para Penghadap pada minuta akta. Tetapi, hal tersebut akan mempersulit Majelis Pengawas Notaris saat melakukan pemeriksaan rutin dan tidak adanya pedoman aturan bagi Majelis Pengawas Notaris untuk memberikan sanksi terhadap Notaris perihal sidik jari Penghadap yang dibubuhinya pada minuta akta sehingga tidak

${ }^{18}$ Hans Kelsen. (2016). Teori Hukum Murni. Bandung: Nusamedia, hal. 138. 
dapat menyatakan apakah Notaris yang inkonsisten dalam membubuhkan sidik jari Penghadap tersebut melanggar atau tidak melanggar.

\section{Kesimpulan}

Pasal 16 (1) c UU No. 2/2014 tidak mengatur penjelasan perihal sidik jari Penghadap yang dibubuhi di minuta akta Notaris. Oleh sebab itu, maka Notaris bebas untuk menggunakan penafsiran manapun mengenai sidik jari mana yang akan dipakai dan bebas untuk menentukan pembubuhan sidik jari dilakukan juga bagi Para Penghadap yang mampu untuk tanda tangan ataukah hanya penghadap yang tidak mampu untuk tanda tangan dan Notaris harus konsisten selama menjalankan tugas jabatan untuk menetapkan sidik jari mana yang akan dibubuhkan oleh Penghadap. Mengenai konsekuensi bagi Notaris terhadap minuta akta yang pembubuhan sidikjari penghadapnya berbeda-beda tidak tegas diatur dalam peraturan perundang-undangan. Mengenai hal tersebut, maka perlu tegas diatur mengenai sidik jari Penghadap dalam minuta akta agar adanya keselarasan setiap Notaris dan perlu diatur lebih lanjut mengenai konsekuensi apabila Notaris inkonsisten dalam membubuhi sidik jari Penghadap dalam minuta akta agar tidak menyulitkan Majelis Pengawas Notaris pada saat melakukan pemeriksaan rutin.

\section{Daftar Pustaka}

$\underline{\text { Buku }}$

Adjie Habib. (2017). Penafsiran Tematik Hukum Notaris Indonesia Berdasarkan Undang-Undang Nomor 2 Tahun 2014 tentang Perubahan Atas Undang-Undang Nomor 30 Tahun 2004 tentang Jabatan Notaris. Bandung : Refika Aditama

Kelsen Hans. (2016). Teori Hukum Murni. Bandung: Nusamedia

Salim H, et.al. (2014). Perancangan KontrakEMemorandum of Understanding (MoU). Jakarta: Sinar Grafika

Suratman dan H.Philips Dillah. (2015). Metode Penelitian Hukum. Bandung:Alfabeta

\section{Jurnal}

Anand, G. (2017). Keabsahan Akta Notaris Kaitannya dengan Kewajiban Pembubuhan Sidak Jari Penghadap. Lambung Mangkurat Law Journal, 2(1), 144856, e-ISSN: 25023128, http://lamlaj.ulm.ac.id/web/.

Dewi, A. S. K. (2016). Penyelenggaraan RUPS Melalui Media Elektronik Terkait Kewajiban Notaris Melekatkan Sidik Jari Penghadap. Arena Hukum, 8(1), 108-126, doi https://doi.org/10.21776/ub.arenahukum.2015.00801.7.

Dewi, W. W., \& Ibrahim, R. Kekuatan Hukum Pelekatan Sidik Jari Penghadap Oleh Notaris Pada Minuta Akta. Acta Comitas: Jurnal Hukum Kenotariatan, 5(3), 436-445, doi https://doi.org/10.24843/AC.2020.v05.i03.p01.

Maharani, I. G. A. A. D. Kewenangan Notaris dalam Transaksi Jual Beli Tanah dan Bangunan: Studi Kasus Penahanan Sertipikat Hak Guna Bangunan. Kertha Patrika, 40(2), 112-121, doi https://doi.org/10.24843/KP.2018.v40.i02.p05.

Mahmoud, A. R. (2014). Implikasi Hukum Bagi Notaris Yang Tidak Melekatkan Sidik Jari Penghadap Pada Minuta Akta. Kumpulan Jurnal Mahasiswa Fakultas Hukum, 1(1). EISSN 2723-3766,

https://ejournal.fh.unmul.ac.id/index.php/risalah/article/view/101. 
Rahmawati, R. (2019). Implementasi Kewajiban Notaris untuk Melekatkan Sidik Jari Para Penghadap pada Minuta Akta. Sasi, 25(1), 1-12, doi https://doi.org/10.47268/sasi.v25i1.138.

\section{Disertasi}

NIGITA, V. (2017). URGENSI DAN IMPLIKASI HUKUM PENERAPAN SIDIK IARI PENGHADAP/PARA PENGHADAP/PARA PIHAK PADA MINUTA AKTA NOTARIS (STUDI TERHADAP PASAL 16 AYAT (1) HURUF C UNDANG-UNDANG NOMOR 2 TAHUN 2014 TENTANG JABATAN NOTARIS) (Doctoral dissertation, Universitas Islam Indonesia).

Ratnawati, A. (2015). Peranan Notaris Untuk Pembuatan Akta Pendirian (CV) dalam Mewujudkan Kepastian Hukum (Doctoral dissertation, Sebelas Maret University).

\section{Peraturan Perundang-Undangan}

Kitab Undang-Undang Hukum Perdata

Undang-Undang Nomor 30 Tahun 2004 Tentang Jabatan Notaris (Lembaran Negara Republik Indonesia Tahun 2004 Tahun 117, Tambahan Lembaran Negara Republik Indonesia Nomor 4432)

Undang-Undang Nomor 2 Tahun 2014 Tentang Perubahan Atas Undang-Undang Nomor 30 Tahun 2004 Tentang Jabatan Notaris (Lembaran Negara Republik Indonesia Tahun 2014 Nomor 3, Tambahan Lembaran Negara Republik Indonesia Nomor 5491) 